DOI https://doi.org/10.18551/rjoas.2018-07.31

\title{
SOCIAL WELFARE: THE ANALYSIS OF SOCIAL CAPITAL OF SMALLHOLDER FARMERS
}

\author{
Agung Dwijatenaya Ida Bagus Made* \\ Faculty of Agriculture, University of Kutai Kartanegara, Indonesia \\ Kardinar Wijayanti Silvana \\ Tenggarong School of Economics, East Kalimantan, Indonesia \\ *E-mail:dwijatenaya@yahoo.co.id
}

\begin{abstract}
The role of social capital on social welfare has been attracting interest from academicians. Indonesia as an agriculture country describes its demography with many smallholder farmers. Thus, the main purpose of this study was to investigate the effects of social capital of smallholder farmers on social welfare. The instrument used to collect data was questionnaire. The number of sample determined by using Slovin's formula then with Proportionate Stratified Random Sampling technique, the selection of the sample, which was groups of smallholder farmers in Kutai Kartanegara Regency. The hypotheses tested using the Product Statistics and Service Solution version 22.0 for Windows. Results of this study revealed that social capital has a positive and significant impact on social welfare. The influence of trust on welfare is positive but not significant. The influence of social network on welfare is positive and significant. The effect of social norms is not significant on welfare. Increasing trust in the members of farmer groups must be taken into consideration by building networks and promoting social norms. However, this effort cannot separated from the behavior of the leaders in this country, thus the public's trust keeps on decreasing.
\end{abstract}

\section{KEY WORDS}

Welfare, social capital, trust, networking, norms.

Every country in this world shares similar goal, which is to promote the welfare of its people. Similarly, Indonesia has been doing various efforts in the context of community welfare improvement. The nation has done various poverty alleviation programs, including in Kutai Kartanegara, one of the most natural resources endowed regencies in Indonesia, located in East Kalimantan Province. Although various poverty alleviation programs have been undertaken, they could not significantly reduce the poverty. In the Regency, the number of poverty can still be categorized as high despite the data shows a decreasing trend. In 2005, poor people in Kutai Kartanegara Regency amounted 56.99 thousand people while in 2017 it decreased to 56.57 thousand people (Indonesia Central Agency for Statistics, 2018).

The problems of poverty faced by developing nations, including Indonesia require various strategies to address the problems. Many experts argue that in addition to economic capital and human capital, the social capital of society is very decisive performance that ultimately affects the welfare. The most important key for development of smallholder farmer society is social capital. This can be seen from the life of farmers who promote mutual cooperation in every activity and the existence of mutual help to help among transmigrated people, as well as the existence of social norms including religious norms that are still upheld by the peasant community. As Coleman pointed out in Mangkuprawira (2010) that social capital facilitates individuals and groups who are developed by networks, beliefs, and social norms. Social capital is a neutral resource that facilitates community-dependent activities. Similarly, people who are members of the farmer group, then the ability of each member in utilizing social capital will be able to improve their welfare. Some experts believe that social capital can improve people's lives. If social capital can be managed properly, then the social 
welfare of the community will increase (Baiyegunhi (2013), Handoyo (2013), Nasution, et al. (2014), Wuysang (2014), and Rohmani, et al. (2015)).

Social capital owned by each member of the farmer's group, if used well, it will be able to improve the welfare. As a case study in Kelurahan Bukit Biru, Tenggarong (Sub-district of Kutai Kartanegara Regency), whether social capital can be utilized properly so that it can improve welfare. Therefore, this study aims to analyze the influence of social capital on social welfare, analyze the influence of trust on welfare, analyze the influence of social networks on welfare, and analyze the influence of social norms on welfare.

\section{LITERATURE REVIEW AND HYPOTHESES}

Welfare. The realization of a country's development success is shown through the increasing public welfare. As Nicholson (2002) puts it, micro-household welfare can be approximated by the Engel curve, which states that the share of food expenditure on household expenditure will diminish with rising incomes. Furthermore, in the state of the price of goods and people's tastes, the increase in income shows an increase in welfare. According to Spicker; Midgley; Tracy and Livermore; Thompson (in Suharto, 2006) the notion of welfare contains at least four meanings, which include; as well-being, as social services, in the form of social security, health services, education, housing, and personal social services, as social benefits, which are especially given to the poor, and as a planned process or business undertaken by individuals, social institutions, communities, and government agencies to improve the quality of life through the provision of social services, as well as social benefits. Stiglitz et al. (2011) states that social welfare is composed of the various demands that accompany it; standard of living material (income, consumption, and wealth), health, education, individual activities including work, political voice, and governance, social relationships and kinship, environment (present and future conditions), insecurity, or physical. All of these dimensions show the quality of life of the people and to measure it requires objective and subjective data. Further Stiglitz et al. (2) health, (3) education, (4) individual activities including work, (5) the basic dimensions to be taken into account in measuring wellbeing are (1) standard of living (income, consumption and wealth); ) political and governance voices, (6) social relationships and kinship, (7) the environment (present and future conditions), and (8) insecurity, both economic and physical. All of these dimensions show the quality of life of the people and to measure it requires objective and subjective data. Research on the influence of social capital on welfare in Indonesia has not been done. Several studies on the effect of social capital on welfare are conducted by the following researchers. Meniarta, et al. (2009) research results are social capital in the form of values, mechanisms and institutions overcome various problems including welfare issues. Pramono's (2012) research findings are social capital has no significant effect on household poverty. Handoyo (2013) research findings are social capital especially trust and net-work contribute in improving welfare. The findings of Baiyegunhi (2013) study that social capital has a positive and significant impact on the welfare of rural households. Nasution, et al. (2014) research findings is increased access to social capital affecting the increase of rural household welfare. Wuysang (2014) the result of his research is social capital positively related to the income of farmer group members. The results of Rohmani's research, et al. (2015) shows the social capital of farm households have a significant effect on welfare. Based on empirical theory studies and empirical studies developed against the influence of social capital (trust, social network, and norms simultaneously affect welfare) are described as follows.

H1: Social capital (trust, social network, and norm) has a significant effect on welfare (Stiglitz, et al., 2011; Baiyegunhi, 2013; Handoyo, 2013; and Nasution, et al., 2014)

Social Capital. According to Putnam in Syahra (2003) social capital is defined as the characteristics of social organization, such as networks, norms, and beliefs that facilitate coordination and cooperation to get the joint benefits (features of social organization, such as networks, norms, and trusts, that facilitate coordination and co-operation for mutual benefit). Simply put, social capital is a characteristic of social organization that facilitates coordination 
and cooperation for mutual benefit. Arsyad, et al. (2011) explains that social capital is a bottom-up phenomenon derived from a set of individuals forming a social network pattern based on the principles of mutual trust, social reciprocity, norms of conduct, and collective action. Furthermore, according to Coleman in Adler and Kwon (2002) social capital is described as Social capital is defined by its function. It is a social entity that describes the value of the relationship social, mutual trust, and mutual norms between individuals and societies Social relations is the most important element in social capital and is a resource.) According to Fujiwara and Kawachi in Thobias et al. (2103) social capital are the resources which is accessed by individuals and groups within a social structure, facilitating cooperation, collective action, and maintaining norms.According to Hasbullah in SyafrilHadi (2014) the core of social capital analysis lies in how people's ability in a group to work together to build a network to achieve common goals The cooperation is colored by a pattern reciprocal and mutually beneficial interrelation and built on trust supported by positive and strong social norms and values.

Trust. Economic welfare can be achieved by optimally utilizing the trust. As Francis Fukuyama in Syahra (2003) that the welfare and competitiveness of a society is determined by the level of trust between fellow citizens. The results of research Kabbaro, et al. (2014) show that trust as a dimension of social capital has a positive and significant impact on the family's objective welfare. The findings of study of Alfiasari (2008) those beliefs have a significant effect on improving the economic welfare of poor families. The results of Fotovvat, et.al. (2014) show that trust has an insignificant effect on sustainable development. Furthermore, the hypothesis that can be built based on theoretical and empirical studies is described as follows.

H2: Trust has a significant effect on welfare (Fukuyama in Syahra, 2013; Alfiasari, 2008; and Kabbaro, et.al., 2014).

Social networks. The social network of farming communities in Bukit Biru Village Tenggarong Sub-district, Kutai Kartanegara Regency of East Kalimantan is formed from various factors, among others, the similarity of religion that is shared and are both transmigration communities. The farmer groups formed on the basis of a common goal. As argued by Hasbulah in Supono (2011) that participation in a network is an element of social capital. Groups built on the basis of common orientation and goals with more modern organizational management features, have better participation rates, and a wider range of networks. Alfiasari (2008) research results show that social networks have a significant effect on improving the economic welfare of poor families. Zuhri's research, et al. (2012) concluded that villagers who have relatively strong social capital then the level of people's welfare tend to be high. The strength of social capital is determined by strong organizational networks. Research findings Kabbaro, et al. (2014) is a social network is an element of social capital has a significant effect on the family's objective welfare. Based on the above study the hypotheses that can be constructed are described as follows.

H3: Social Network has significant effect on welfare (Hasbulah in Supono, 2011; Alfiasari, 2008; and Kabbaro, et al., 2014).

Social norm (Norms). The norms that were built among the members of the farmer's group in the Bukit Biru Village Tenggarong Sub-district of Kutai Kartenagara Regency were inseparable from the norm from which the farmers came from. Because the farmers are transmigrants that taste from Java Island, the social norms and customs of Java are dominant in this farmer group. According to Fukuyama in Adler and Kwon (2002) social capital is defined as a set of informal values or norms exchanged to the group to enable them to work together as a result of a certain set of informal values or norms shared among members of a group that permit cooperation among them). Svendsen and Svendsen in Rohmani, et al. (2015) norms are the basis of the actors to build joint activities. The results of Kabbaro, et al. (2014) showed a high average index of total suspension. The influence of norms on objective wellbeing is not significant. The finding of Alfiasari (2008) is a written norm having a significant effect on the objective welfare. However, the unwritten norms, traditional norms, and religious norms have nothing to do with improving the economic 
welfare of poor families. The hypothesis that can be constructed based on theoretical and empirical studies is described as follows.

H4: Social norms have a significant effect on welfare (Fukuyama in Adler and Kwon, 2002 and Alfiasari, 2008).

According to theoretical and empirical studies, shown that social capital affects welfare. This study has similarities with previous research which is to examine the effect of social capital on welfare. However, this study also emphasizes on the investigation of the effects of social capital consists of trust, network, and social norms towards social welfare of farmer group members in rural areas. The similarities and differences of this study with previous research are explained in the discussions. In order to clarify, the conceptual framework of this study is illustrated as in Figure 1.

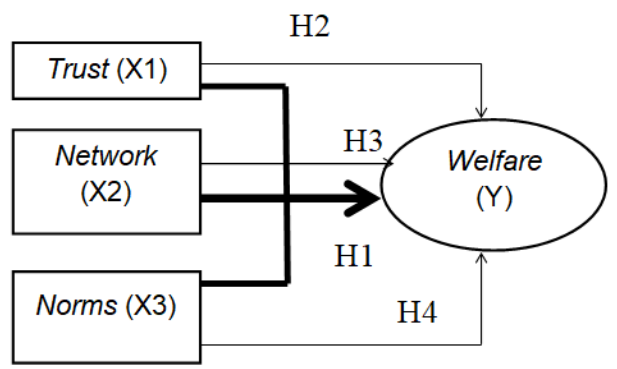

Figure 1 - Theoretical Framework

\section{RESEARCH METHODOLOGY}

This study used quantitative approaches. Sugiyono (2012) describes the research design using quantitative methods is one type of research that the specification is systematic, well planned and structured clearly from the beginning to the research design. The objects of this research were social welfare and social capital of smallholder farmers including farmer groups such as Harapan Maju, Lumbung Paceklik, Karya Tani, and Berkat Sentosa located in Bukit Biru sub-district Tenggarong, Kutai Kartnegara Regency, East Kalimantan. Social Welfare acted as the dependent variable $(Y)$ while social capital sub variables such as trust $(\mathrm{X} 1)$, social networks (X2) and social norms (X3) played as independent variables.

Primary data collected and obtained directly from the respondents whereas secondary data such as statistical numbers of smallholder farmers in Kutai Kartanegara Regency, information regarding the geographical area of this study and the condition of the poor were obtained from the official websites of Central Agency on Statistics of Kutai Kartanegara and Central Agency on Statistics of East Kalimantan.

Population of this study was 97 people and using Slovin formula (Sedarmayanti and Hidayat, 2002: 143) at the level of sampling error of 10 percent to obtain 49 respondents. Furthermore, to select the sample, researcher used proportionate stratified random sampling. As noted by Sekaran (2006), population stratification can be done based on region. For that reason, the number of samples of each farmer group was determined proportionally (Sugiyono, 2012), so that the number of samples for Harapan Maju farmer group was 14 people, 12 people of Lumbung Paceklik, 12 people of Karya Tani , and 11 people for Berkat Sentosa group.

The research instrument used in this study was questionnaire (structured interview). Measurement of research variables were based on indicators in the form of questions and statements to become research instruments. Validity and reliability tests for each question item was done through pilot test by distributing the questionnaire to 30 respondents. With Cronbach's Alpha value 0.916 (>0.6), it means that the question items were reliable (Triton in Sujianto, 2009). The validity test results are valid ( $r$ counted $>0.3$. Sugiyono (2012) stated that a question is valid if it has a correlation value ( $r$ counted) greater than the correlation value of 0.3 ( $r$ count $>0.3$ ). 
The analysis model used to test the proposed hypothesis is the Multiple Regresion Linear model. The multiple regression analysis with the least squares equation is formulated as follows (Supranto, 2001).

$$
\mathrm{Y}=\mathrm{b} 0+\mathrm{b} 1 \mathrm{X} 1+\mathrm{b} 2 \mathrm{X} 2+\mathrm{b} 3 \mathrm{X} 3+\mathrm{e}
$$

Where: $Y=$ Social Welfare; $b 0=$ constants; $b 1,2,3=$ Regression coefficient of each independent variable; $\mathrm{X} 1$ = Trust; $\mathrm{X} 2$ = Social Network; $\mathrm{X} 3$ = Norm; e = Residual variable.

$F$ test was used to prove whether social capital has simultaneous influence to social welfare. The $t$ test was used to test the influence of each independent variable used in this study to the dependent variable partially. In order to ensure that the data was feasible to be analyzed with regression methods, we ran classical assumption tests.

Normality test. According to One-Sample Kolmogorov-Smirnov table, obtained the probability value or Asym.Sig (2-tailed) value greater than 0.05 . This indicates that the data are normally distributed (Sujianto, 2009), as Table 1.

Table 1 - Normality Test Result, 2018

\begin{tabular}{lll}
\hline Variable & Asymp. Sig. (2-tailed) & Remarks \\
\hline Trust $(\mathrm{X} 1)$ & 0.510 & Nilai $p>0.05=$ normal \\
Network $(\mathrm{X} 2)$ & 0.195 & Nilai $\mathrm{p}>0.05=$ normal \\
Norms $(\mathrm{X} 3)$ & 0.214 & Nilai $\mathrm{p}>0.05=$ normal \\
Social Welafare $(\mathrm{Y})$ & 0.101 & Nilai $\mathrm{p}>0.05=$ normal \\
\hline
\end{tabular}

Source: Primary Data Processed by the Researcher.

Multicollinearity. The test results indicate that the VIF values for all independent variables (X) were less than 10 as shown in Table 2 below. It means that the independent variables are free from multicollinearity (Sujianto, 2009).

Table 2 - Multicollinearity Test Results, 2018

\begin{tabular}{lll}
\hline VariabLE & Tolerance & VIF \\
\hline Trust $(\mathrm{X} 1)$ & 0.639 & 1.566 \\
Network $(\mathrm{X} 2)$ & 0.559 & 1.789 \\
Norms $(\mathrm{X} 3)$ & 0.522 & 1.915 \\
\hline
\end{tabular}

Source: Primary Data Processed by the Researcher.

Heteroscedasticity. Heteroscedasticity test was done by correlating independent variables with $A B R E S$. If the value of $P$ value (significance) $>0,05$, then concluded there is no heteroscedasticity. The test results showed that $P$ value $>0,05$ as Table 3 below:

Table 3 - Heteroscedasticity Test Results, 2018

\begin{tabular}{ll}
\hline Variable & P Value (Sig.) \\
\hline Trust $(\mathrm{X} 1)$ & 0.971 \\
Network $(\mathrm{X} 2)$ & 0.457 \\
Norms $(\mathrm{X} 3)$ & 0.601 \\
\hline
\end{tabular}

Source: Primary Data Processed by the Researcher.

Autocorrelation. The autocorrelation test was performed by using Durbin Watson test (DW test). The test results showed that there was no autocorrelation. This is indicated by the $\mathrm{dW}$ value of 1.827 , dU of 1.673 , and $\mathrm{dL}=1.4136$. The criteria of assessment as defined by Makridaktis in Sujianto (2009) if $\mathrm{dU}<\mathrm{dW}<4-\mathrm{dU}$, then there is no autocorrelation $(1,673$ $<1,827<2,327)$.

\section{RESULTS AND DISCUSSION}

General Descriptions of Research Area. The total area of Kelurahan Bukit Biru, Tenggarong is 3,505 ha where the distance from the capital city of regency as the center of 
government is about $3.5 \mathrm{~km}$. The boundaries of Kelurahan Bukit Biru is in the west by Jahab, Rempanga in the east, South is bordered by Sumber Sari Village, Loa Kulu while the North is adjacent to Timbau Urban Village. Kelurahan Bukit Biru is a village that has a large agricultural area compared to other urban villages in Tenggarong sub-district. The livelihood of the population is mostly as a farmer $(30 \%)$ and most of their highest education level is only at elementary school (38 percent), (Kutai Kartanegara Central Agency on Statistics, 2017).

Descriptions of Research Variables. Social welfare of smallholder farmers was analyzed through social capital analysis consisting of three elements namely trust, social network, and social norms. Thus, the research variables consists of a dependent variable and 3 independent variables. Dependent variable was social welfare $(Y)$ measured through 5 indicators such as increasing asset ownership (Y1.1), income increase (Y1.2), family health increase (Y1.3), education of family member increase (Y1.4), and social kinship increase (Y1.5).

On the other hand, independent variables consist of 3 elements of social capital such as trust, social network, and social norms. Trust (X1) measured through 5 indicators namely trust building between members of farmer group (X1.1); trust towards rules exist in the group (X1.2); the level of trust of the members towards their group leader (X1.3); the level of trust of the members towards GAPOKTAN leader (X1.4); and the level of trust of the members towards extension workers (X1.5). Social network (X2) measured through 5 indicators such as Information spread widely among fellow farmer group members (X2.1); the mutual help between the members (X2.2); There is mutual cooperation between members (X2.3); technical assistance from the government (X2.4); and the role of private / NGOs in developing the farmer groups (X2.5). Social norms (X3) also measured through 5 indicators. Firstly, there is monthly discussion regarding each activity (X3.1); the frequency of discussion for every mutual cooperation activity (X3.2); rules within group is well implemented (X3.3); there is a habit of mutual cooperation (X3.4); and knowing that there is religious guidance in group activities (X3.5).

Table 4 - Descriptive Statistics of Research Variables, 2018

\begin{tabular}{|c|c|c|c|c|c|c|c|c|c|c|c|c|c|c|}
\hline \multirow{3}{*}{ Variable } & \multirow{3}{*}{ Indicator } & \multicolumn{12}{|c|}{ Score } & \multirow{3}{*}{ Mean } \\
\hline & & \multicolumn{2}{|c|}{1} & \multicolumn{2}{|c|}{2} & \multicolumn{2}{|c|}{3} & \multicolumn{2}{|c|}{4} & \multicolumn{2}{|c|}{5} & \multicolumn{2}{|c|}{6} & \\
\hline & & $F$ & $\%$ & $\mathrm{~F}$ & $\%$ & $\mathrm{~F}$ & $\%$ & $\mathrm{~F}$ & $\%$ & $\mathrm{~F}$ & $\%$ & $\mathrm{~F}$ & $\%$ & \\
\hline \multirow[t]{3}{*}{ Welfare $(Y)$} & Y1 & 0 & 0 & 0 & 0 & 2 & 4,1 & 14 & 28,6 & 27 & 55,1 & 6 & 12,2 & 4.75 \\
\hline & Y2 & 0 & 0 & 0 & 0 & 2 & 4,1 & 19 & 38,8 & 22 & 44,9 & 6 & 12,2 & 4,65 \\
\hline & Y3 & 0 & 0 & 0 & 0 & 3 & 6,1 & 18 & 36,7 & 24 & 49,0 & 4 & 8,2 & 4,59 \\
\hline \multirow[t]{2}{*}{ Total Welfare } & Y4 & 0 & 0 & 0 & 0 & 3 & 6,1 & 19 & 38,8 & 23 & 46,9 & 4 & 8,2 & 4,57 \\
\hline & Y5 & 0 & 0 & 0 & 0 & 2 & 4,1 & 14 & 28,6 & 27 & 55,1 & 6 & 12,2 & $\begin{array}{r}4,76 \\
23,32\end{array}$ \\
\hline \multirow[t]{3}{*}{ Trust (X1) } & $\mathrm{X} 1.1$ & 0 & 0 & 0 & 0 & 1 & 2,0 & 13 & 26,5 & 29 & 59,2 & 6 & 12,2 & 4.82 \\
\hline & X1.2 & 0 & 0 & 0 & 0 & 8 & 16,3 & 20 & 40,8 & 18 & 36,7 & 3 & 6.1 & 4.33 \\
\hline & $\times 1.3$ & 0 & 0 & 0 & 0 & 5 & 10,2 & 17 & 34,7 & 24 & 49,0 & 3 & 6,1 & 4.51 \\
\hline \multirow[t]{2}{*}{ Total Trust } & X1.4 & 0 & 0 & 1 & 2,0 & 10 & 20,4 & 15 & 30,6 & 22 & 44,9 & 1 & 2,0 & 4.24 \\
\hline & X1.5 & 0 & 0 & 0 & 0 & 4 & 8,2 & 8 & 16,3 & 34 & 69,4 & 3 & 6,1 & $\begin{array}{r}4.73 \\
22,63\end{array}$ \\
\hline \multirow[t]{3}{*}{ Network (X2) } & $\mathrm{X} 2.1$ & 0 & 0 & 0 & 0 & 5 & 10,2 & 16 & 32,7 & 26 & 53,1 & 2 & 4,1 & 4.51 \\
\hline & $X 2.2$ & 0 & 0 & 0 & 0 & 1 & 2,0 & 17 & 34,7 & 29 & 59,2 & 2 & 4,1 & 4.65 \\
\hline & X2.3 & 0 & 0 & 2 & 4,1 & 3 & 6,1 & 21 & 42,9 & 22 & 44,9 & 1 & 2,0 & 4.35 \\
\hline \multirow[t]{3}{*}{ Total Network } & $X 2.4$ & 0 & 0 & 0 & 0 & 4 & 8,2 & 18 & 36,7 & 26 & 53,1 & 1 & 2,0 & 4.49 \\
\hline & $\times 2.5$ & 0 & 0 & 0 & 0 & 5 & 10,2 & 15 & 30,6 & 25 & 51,0 & 4 & 8,2 & 4.57 \\
\hline & & & & & & & & & & & & & & 22,57 \\
\hline \multirow[t]{3}{*}{ Norms (X3) } & X3.1 & 0 & 0 & 0 & 0 & 2 & 4,1 & 24 & 49,0 & 19 & 38,8 & 4 & 8,2 & 4.51 \\
\hline & X3.2 & 0 & 0 & 0 & 0 & 0 & 0 & 25 & 51,0 & 22 & 44,9 & 2 & 4,1 & 4.53 \\
\hline & X3.3 & 0 & 0 & 0 & 0 & 8 & 16,3 & 20 & 40,8 & 20 & 40,8 & 1 & 2,0 & 4.29 \\
\hline \multirow[t]{2}{*}{ Total Norms } & $\times 3.4$ & 0 & 0 & 0 & 0 & 3 & 6,1 & 14 & 28,6 & 27 & 55,1 & 5 & 10,2 & 4.69 \\
\hline & X3.5 & 0 & 0 & 0 & 0 & 1 & 2,0 & 16 & 32,7 & 28 & 57,1 & 4 & 8,2 & $\begin{array}{r}4.71 \\
\end{array}$ \\
\hline
\end{tabular}

Source: Primary Data Processed by the Researcher.

Table 4 above shows respondents' answers to social welfare with an average score of 23.32. This means that the majority of farmers declare that the level of people's welfare is in 
the prosperous category. Welfare as measured by indicators of increased asset ownership, income increase, health status, educational degree, and social kinship were grouped in positive answers.

Trust of smallholder farmer community has been built since long time ago in Bukit Biru Village, shown from respondents' answers which stated that the trust between members, the level of trust toward the leader the farmer group, the trust level towards Gapoktan, and the trust level towards instructors were grouped in the good category.

The society who lives in Bukit Biru mostly came from villages in Java through transmigration program of the previous President. For that, social network tends to more strongly formed than other society. Average score of respondents' answers on social network was 22.57. This implies that the social network within them categorized as good. Any information received regarding welfare improvements spreads among fellow members well. This is because they share same emotions and feelings of being transmigrated individuals, so they tend help each other to stand up. Every effort for welfare improvements done through well managed mutual cooperation. The roles of extension officers and the private sector are running fairly well, as transmigration is part of government programs. This can be seen from the answers of respondents clustered on a positive answer.

Next, average score of respondents' answers on social norms was 22.73 . This means that the social norms available are quite good. The existence of musyawarah (the Indonesian term for group discussion) in every activity including mutual cooperation activities become guideline for every member to act. In addition, the existence of religious norms and customs provide a standard for holding the norms to achieve common prosperity.

The Effect of Social Capital on the Social Welfare of Smallholder Farmers. Hypotheses tested using multiple linear regression analysis model with 95 percent confidence level $(\alpha=0,05)$. The results of the regression analysis were summarized in table 6 below:

Table 6 - Summary of Results of Multiple Linear Regression Analysis the Effect of Social Capital on Social Welfare, 2018

\begin{tabular}{llll}
\hline Variable & Coefficient & t Value & Sig. \\
\hline Trust $(\mathrm{X} 1)$ & 0.123 & 0.795 & 0.431 \\
Network $(\mathrm{X} 2)$ & 0.457 & 2.935 & 0.005 \\
Norms $(\mathrm{X} 3)$ & 0.054 & 0.339 & 0.736 \\
\hline Constanta $=7.387 \mathrm{~F}$ count $=7.118$, Sig. $=.001$ & & \\
$\mathrm{R}=0,567 \mathrm{R}^{2}=0,322 \mathrm{~F}$ table $=3,23 \mathrm{t}$ table $=1,68$ & & \\
\hline
\end{tabular}

Source: Primary Data Processed by the Researcher.

Based on table 6, we get the following regression equations:

$$
Y=7,387+0,123 X 1+0,457 X 2+0,054 X 3
$$

Where according to the equations, we can interpret that:

- The constant value of 7,387 means that if there is no social capital, the welfare of smallholder farmers in Bukit Biru, Tenggarong is 7,387 units;

- The regression coefficient for Trust (X1) was 0.123 which means that each addition of activities related to public trust will increase social welfare by 0.123 units;

- The regression coefficient for Social Network (X2) was 0.457 , which means that every change per activity related to social network will increase social welfare by 0.457 units;

- The regression coefficient for social norms was 0,054 , states that every change per activity related to social norms will increase social welfare by 0,054 unit.

On the other hand, according to regression analysis, found that $R$ value was 0,587 (Table 6) which means that social capital measured through trust, social network, and social norms has a moderate relationship with social welfare. The value of $R$ square $\left(R^{2}\right)$ of 0.322 shows that the social capital was able to explain its effect on the social welfare of smallholder farmers by $32.2 \%$, while the rest $67.8 \%$ was explained by other variables which were not included in the model. According to Sugiyono (2012), it is classified as low effects. 
Furthermore, based on the value of $F$ count compared to $F$ table $(7.118>3.23)$, can be concluded that the proposed hypothesis $(\mathrm{H} 1)$ confirmed, ie social capital consisting of elements of trust, social network, and social norms positively and significantly affect the social welfare. This result is in line with Baiyegunhi (2013); Handoyo, (2013); and Nasution, et al., (2014). However, the findings contrary to Pramono (2012). The growing trust of the members, either it is trust between members, trust in the leader of the farmer group, trust in Gapoktan leader, or trust in extension workers, if it is supported by the existence of social networks, and adherence to the prevailing norms, it can improve social welfare.

The Effect of Trust on Social Welfare. The effect of trust on social welfare was partially tested with $\mathrm{t}$ test. Based on the statistical test, found that the $\mathrm{t}$ count value was smaller than $\mathrm{t}$ table $(0.795<1.68$; significance level 0.0431$)$. This means that partially trust has positive but not significant effect on social welfare. This result rejected hypothesis $(\mathrm{H} 2)$ of this study and the findings from Alfiasari (2008) and Kabbaro, et al. (2014) which stated that trust has a significant effect on welfare.

The effect of Social Networks on Social Welfare. The effect of social networks on social welfare tested using $\mathrm{t}$ test and found that the $\mathrm{t}$ count value was greater than $\mathrm{t}$ table $(2.935<$ 1.68; significance level 0.005). This means that social networks affects positively and significantly to social welfare. Hence, hypothesis $(\mathrm{H} 3)$ confirmed. The social network built in the smallholder farmer community in Bukit Biru, Tenggarong can not be separated from the fact that they are transmigrated community. Thus, the mutual emotions are still strong for each other, making any information gained regarding welfare improvements is quickly communicated to fellow members. The mutual help that manifests from mutual cooperation between members is still quite good despite being plagued by the growing influences of globalization. In addition, the roles of government through extension and private role are still good.

The research findings that social networks have a positive and significant impact on welfare confirmed the findings of Hasbulah in Supono (2011); Alfiasari (2008); Zuhri, et al. (2012); and Kabbaro, et al. (2014). The common goal of establishing farmer groups is to improve welfare. Information as a source of change can quickly spread to each member, so that activities carried out in mutual assistance to help each other accelerate the achievement of welfare. In addition, coaching by extension workers and private parties also strengthens the social network so that welfare improvement can be more easily achieved.

The Effect of Social Norms on Welfare. The effect of social norms on social welfare tested using $t$ test and found that the $t$ count value was samller than $t$ table $(0.054<1.68$; significance level 0.736). This means that the effect of social norms on welfare is not significant (Hypothesis (H4) rejected). Although not significant, the effect of social norms on social welfare showing positive value. The findings of this study differ from Alfiasari (2008) which stated that social norms have a significant effect on welfare. The findings of this study are consistent with the findings of Kabbaro et al. (2014). Positive value of social norms implies that even though partially it seems to be weak in influencing social welfare, but the social norm namely gotong royong (Indonesian term for mutual cooperation) is one of the characteristics of the society which still well implemented. All activities such as discussion and mutual cooperation do not apart from the norms of customs and religion of the group.

\section{CONCLUSION}

This study aimed to investigate the effect of social capital on social welfare of smallholder farmers. Proposing four hypotheses, the results of the study revealed that we could only confirm two of them. Firstly, this study found that social capital positively and significantly affects social welfare of smallholder farmers. Besides that, this study also found that social network has positive and significant effect on social welfare. Although showing positive value, the effects of trust and social norms revealed to be insignificant on social welfare. Increasing trust in the members of farmer groups must be taken into consideration by building networks and promoting social norms. However, this effort can not separated from the behavior of the leaders in this country, thus the public's trust keeps on decreasing. 
Since the model of this study was only able to explain about social welfare improvement by $32.2 \%$, so further research can add some other variables or sub variables into the model. Besides that, further study can also widen the sample size to make the result of the study more generalizable.

\section{REFERENCES}

1. Adler, Paul S. and Seok-Woo Kwon. (2002). Social capital: Prospect or a new concept. Academy of Management Review, 27(1). 17-40.

2. Alfiasari. (2008). Analisis Modal Sosial dalam Pemberdayaan Ekonomi Keluarga Miskin Di Kelurahan Kedung Jaya, Kecamatan Tanah Sareal, Kota Bogor. Jurnal Ilmu Keluarga \& Konsumen, 1(1), 29-42.

3. Arsyad, Lincolin, Elan Satriawan, Jangkung Handoyo, dan Ardyanto Fitrady. (2011). Strategi Pembangunan Perdesaan Berbasis Lokal. Yogyakarta: Unit Penerbit dan Percetakan STIM YKPN.

4. Badan Pusat Statistik Kabupaten Kutai Kartanegara. (2017). Kabupaten Kutai Kartanegara Dalam Angka. Tenggarong: Badan Pusat Statistik Kabupaten Kutai Kartanegara

5. Badan Pusat Statistik Provinsi Kalimantan Timur. (2018). Jumlah Penduduk Miskin Kalimantan Timur menurut Kabupaten/Kota (ribu jiwa), 2015-2017. Samarinda: Badan Pusat Statistik Provinsi Kalimantan Timur.

6. Baiyegunhi, Lloyd J. S. (2013). Rural houshold' social capital and welfare: A case study of Msinga, KwwaZulu-Natal, South Africa. Journal of Agriculture and Rural Development in the Tropics an Subtopics, 114(2), 123-132.

7. Easterlin, Richard A. (2001). Income and Happiness: Towards a Unified Theory. The Economic Journal. 111(July), 465-484.

8. Fotovvat, Shabnam, karam Safari, Karamollah Zayyari, and Somayeh boostani. (2013). A study on relationship between social capital and sustainable development. Management Science Letters. 4(2014). 2117-2120.

9. Handoyo, Eko. (2013). Kontribusi Modal Sosial Dalam Meningkatkan Kesejahteraan Pedagang Kaki lima Pasca Relokasi. Jurnal Komunitas, 5(2), 252-266.

10. Kabbaro, Hurriyyatun, Hartoyo, dan Lilik Noor Yuliati. (2014). Modal sosial, strategi koping ekonomi, dan kesejahteraan objektif keluarga dengan perempuan sebagai kepala keluarga. Jur.Ilm.Kel \& Kons, 7(3), 164-173.

11. Kitchen, Peter, Allison Williams and Dylan Simone. (2012). Measuring Social Capital in Hamilton, Ontario. Soc Indic Res, 108 (2012), 215-238.

12. Mangkuprawira, Sjafri. (2010). Strategi peningkatan kapasitas modal dan kualitas sumber daya manusia pendamping pembangunan pertanian. Forum Penelitian Agro Ekonomi, 28(1), 19-34.

13. Meniarta, I Ketut, Wawan Ma'udi, dan AAGN Ari Dwipayana. (2009). Dinamika Sistem Kesejahteraan dan Modal Sosial di Masyarakat Banjar Pekraman Bali. Jurnal Ilmu Sosial dan Ilmu Politik. 13(2), 231-248.

14. Nasution, Ahmadriswan, Ernan Rustiadi, Bambang Juanda, dan Setia Hadi. (2014). Dampak Modal Sosial Terhadap Kesejahteraan Rumah Tangga Perdesaan di Indonesia. Mimbar, 30(2), 137-148.

15. Nicholson, Walter. (2002). Mikroekonomi Intermediate Dan Aplikasinya. Edisi Ke Delapan. (IGN Bayu Mahendra dan Abdul Azis, Pentj). Jakarta: Erlangga.

16. Pramono, St Agung Dwi. (2012). Pengaruh Modal Sosial Terhadap Rumah Tangga Miskin. JEJAK Journal of Economics an Policy, 5(2), 127-229.

17. Rohmani, Sri Asih, Ernan Rustiadi, Muhammad Firdaus, dan Tahlim Sudaryanto. (2015). Dampak Modal Sosial dalam Pengelolaan Irigasi Terhadap Kesejahteraan Petani di Kabupaten Sukoharjo Jawa Tengah. Informatika Pertanian, 24(1), 67-90.

18. Sedarmayanti dan Syarifudin Hidayat. (2002). Metodologi Penelitian. Bandung: CV. Mandar Maju. 
19. Sekaran, Umar. (2006). Research Methodes For Business. Metodologi Penelitian Untuk Bisnis. Buku 2. Edisi 4. Jakarta: Salemba Empat.

20. Stiglitz, Joseph E., Amartaya 294sosialn Jean-Paul Fitoussi. (2011). Mengukur Kesejahteraan Mengapa Produk Domestik Bruto Bukan Tolok Ukur Yang Tepat Untuk Menilai Kemajuan. (Mutiara Arumsari dan Fitri Bintang Timur, Pentj). Bintaro: Marjin Kiri.

21. Sugiyono. (2012). Metode Penelitian Kombinasi (Mixed Methods). Bandung: Penerbit Alfabeta.

22. Suharto, Edi. (2006). Negara Kesejahteraan Dan Reinventing DEPSOS. IRE. Yogyakarta.

23. Sujianto, Agus Eko. (2009). Aplikasi statistik dengan SPSS 16.0. Jakarta: Prestasi Pustaka.

24. Supono, Boedyo. (2011). Peranan Modal Sosial dalam Implementasi Manajemen dan Bisnis. Jurnal Ekonomi dan Kewirausahaan, 11(1), 10-16.

25. Supranto, J. (2001). Statistik Teori dan Aplikasi. Jilid 1 dan 2. Jakarta: Erlangga.

26. SyafrilHadi. (2014). Profil Modal Sosial dan Tingkat Partisipasi Peternak Pada Pengembangan Sapi Potong di Kabupaten Tebo Propinsi Jambi. Kanal, 2(2), 107-206.

27. Syahra, Rusydi. (2003). Modal Sosial: Konsep dan Aplikasi. Jurnal Masyarakat dan Budaya. 5(1).

28. Thobias, Erwin, A.K. Tungka, dan J.J. Rogahang. (2013). Pengaruh Modal Sosial Terhadap Perilaku Kewirausahaan. Jurnal ACTA DIURNA. Edisi April 2013.

29. Wuysang, Rendy.. (2014). Modal Sosial Kelompok Tani Dalam Meningkatkan Pendapatan Keluarga Suatu Studi Dalam Pengembangan Usaha Kelompok Tani di Desa Tincep Kecamatan Sonder. Journal Acta Diurna, III(3).

30. Zuhri, Mursid, Rachman Djamal, dan Eny Hari Widowati. (2012). Penguatan Modal Sosial Kelembagaan Dalam Rangka Penanggulangan Kemiskinan Perdesaan di Jawa Tengah. Jurnal Litbang Provinsi Jawa Tengah, 10(1), 10-18. 